\title{
MORE ON POSSIBLE FOREST ENETS - KET CONTACTS
}

\author{
Florian Siegl \\ University of Helsinki
}

\begin{abstract}
In this paper linguistic traces of the Enets' migration to the Taimyr Peninsula are addressed. Special attention is paid to Forest Enets-Ket contacts and a tentative etymology for the (Forest) Enets' ethnonym for Kets and Selkups is offered. Of special importance is a likely Enets place name in Northern Evenkija, an area from which no Enets place names have been reported earlier. As the same area is inhabited by speakers of the northern dialect of Ket, this area should be seen as a possible contact area for the unusual case of pronoun borrowing in Forest Enets as discussed in Siegl (2008).
\end{abstract}

Keywords: toponymica, language contact, Tundra Enets, Forest Enets, Selkup, Ket, Yeniseic languages

\section{The Enets migration towards the Yeniseian North}

Both Enets languages, Tundra and Forest Enets ${ }^{1}$ are relatively late arrivers on the Taimyr Peninsula and it is generally agreed on that the arrival of the Tundra Enetses preceded the arrival of Forest Enetses. The arrival itself is, of course, difficult to date; based on his excavations, the archeologist Klobystin dated the arrival of the first (Tundra) Enetses to the 9th or 10th century (Klobystin 2005: 169), but for the Forest Enetses on which much more archival and published historical data is available, an arrival as late as the 18th or early 19th century is equally possible (subsumed in Siegl (forthcoming)). Also linguistically, the interpretation that the advent of Tundra and Forest Enetses happened independently is sound as there are no obvious examples for contacts between the speakers of both languages. ${ }^{2}$

1 A discussion concerning the history of these and older ethnonyms takes was published earlier (Siegl 2005) and should be consulted for more background information.

2 It is known that members of several Forest Enets clans left their original territory in the 19th century and moved north. This ended with their 


\section{Traces of the Enets' migration in other Samoyedic languages}

Although the gradual migration of Enetses to the Yeniseian North is well attested in fur tribute lists underlying Dolgix (1970) and subsequent work by Vasil'ev (1979), linguistic traces of the Enets' migration have not been studied in great detail. Prior research has concentrated almost exclusively on traces of Enetses in territories which are nowadays occupied by Northern Selkups (Prokof'ev 1935; Xelimskij 2000).

\subsection{Enets toponymics outside their current ter- ritories}

The following Enets traces were discussed in Prokof'ev (1935) and Xelimskij (2000) and have stood the test of time.

\subsubsection{Mangazeja}

The name of the Russian Fortification Mangazeja (ru: Мангазея) erected in the early 17 th century on the lower Taz has been explained as deriving from an older version of the Enets clan mogad'i, itself based on the lexeme for moga 'wood' $(\leftarrow$ *moykå) and Russian zemlja (ru: земля) 'land, earth'. (Prokof'ev 1935: 10; Xelimskij 2000: 87)

\subsubsection{Verxnaja Bajxa and Nižnaja Baixa}

Both rivers are located on the western bank of the Yenisei close to Turuxansk. Prokof'ev (1935: 10) explains the place

complete assimilation with Tundra Enetses which has been discussed in the literature. The opposite, assimilation of Tundra Enetses with Forest Enetses has never been reported. 
names as deriving from bai, the name of an Enets clan and jaxa 'river' (in contemporary Forest Enets d'oxa; Tundra Enets d'axa) $\sim$ Upper/Lower Enets river.

\subsubsection{Ratta}

The name of an earlier Northern Selkup settlement on the lower Taz, Ratta (ru: Pamma) was etymologized by Xelimskij as deriving from an Enets lexeme underlying lata 'board' in contemporary Forest Enets (2000: 91-93). The change $r \rightarrow l$ in Forest Enets onsets is regular (ibid. 92).

\subsection{Enets patronymics in Northern Selkup}

For the sake of completeness, a short note on Selkup patronymics by Prokof'ev (1935:10) must be mentioned. Two surnames, Mandakov and Polin (ru: Мандаков, Полин) are potentially of Enets origin. Prokof'ev (ibid) etymologizes Мандаков as a compound of mando/maddu (in contemporary Forest Enets madu 'a person speaking a Samoyedic language in the North, either Tundra Enets or Nganasan) and the Selkup noun qup 'person' from which the Russian surname is derived via -ов. Полин matches Болин which is one of the most usual surnames among Forest Enetses.

\section{The designation of linguistic neighbors}

A certain characteristic uniting Nenets, Enets, Selkup and Ket is the fact that several ethnonyms are vague and designate more than one people. ${ }^{3}$ For example, the Tundra Nenets ethnonym $x a b i$ designates a variety of people such as Khantys,

3 This of course also valid for Russian designations, e.g. Ostyak. In isolation, Ostyak designated the Khanty, in compounds such as OstaykSamoyeds the Selkups and Yenisei-Ostyak the Kets. 
Selkups and Kets. ${ }^{4}$ Also the Forest Enets ethnonym bagl'a designates both Selkup and Ket and possibly Khanty though its best translation nowadays is 'people in the south'. For (Northern) Ket, no special ethnonym designating Enetses was known (Alekseenko 2005a: 645). In principal, the same seems to be valid for Northern Selkup. Still, the situation is confusing in this point as there are a variety of co-existing and competing ethnonyms in the literature. ${ }^{5}$

\subsection{A tentative etymology of bagl'a}

Although the designation for 'Ket, Selkup' in both Tundra Nenets and Forest Enets matches semantically, Tundra Nenets $x a b i$ and Forest Enets bagl'a are historically not connected. Besides, an etymological analysis of the Forest Enets designation of 'Ket, Selkup' has never been attempted. Concerning its possible etymology, the lexeme bagl'a seems to contain bag 'hole in the ground' and a derivational suffix in -l'a. The function of the later suffix is partly unclear, but attested in several derivations, e.g. bogl'a 'bear' or the name of an Enets hero bunel'a. In the lexeme for 'bear' bogl'a, the -l'a suffix is non-etymologic and only the first element serves as the base for reconstruction. Although the bear as an animal of taboo has been

4 Different forms and derivations of this ethnonym occupy about a page in Tereščenko (1965: 708). For the sake of completeness it must be mentioned, that the same ethnonym is known to have a second meaning such as 'slave, worker'; this has no direct implications for this paper.

5 As this topic would result in an article of its own, only a short list will be produced. In Donner's materials, Nenetses are refered to as either jura $(k)$ 'jurak-samojedi / Juraksamojede'. Der Name wird selten gebraucht, weil die Tym-Samojeden nie den Juraken begegnen. Dagegen haben die Ostjak-Samojeden vom Vach und Taz oft Kontakt mit den Juraken. (Alatalo 2004: entry 1732) or küəluך Ewenke; (im Norden:) 'Nenze'. (Alatalo 2004: entry 2400). Alekseenko (2005a: 645) mentions a Turkic borrowing калькк 'people' used as a specialized designation for Nenetses and Enetses. Similar forms, though without any etymological comments are mentioned in Erdélyi (1970: 64) as qälikkqwälik 'der Nenze, Jurake' and Kuznecova et al. (1993: 159) qälyk qäl-ira 'Ненец'. 
culturally salient, the animal is treated as a human and instead of the interrogative $o b u$ 'what' še 'who' must be used. As all other instances of -l'a are found on nouns denoting humans, its function expresses apparently human agency. This would allow to etymologize 'Ket, Selkup' as hole-dweller. Such an etymology, even if a scent of folk etymology cannot be denied, can be backed up ethnographically. ${ }^{6}$ Both Selkup and Kets are known to have used earth huts earlier (ru: землянка). According to Alekseenko (2005c: 672), Northern Kets still know such earth huts, but tend to use a borrowing from Evenki golomo instead. Kai Donner's Ket consultant from a slightly more southern location knew this typical winter dwelling as bäyga's (Donner 1933: 25) which can be found in Werner (2002 I: 105, II: 140) as

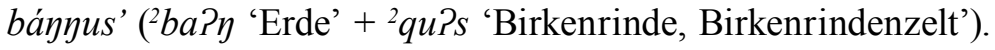
Among Northern Selkups, earth huts were known too (Tučkova 2005: 335-338), though apparently not under one unified name. In Kuznecova et al. (1993: 107) one finds cul' $m \overline{\partial t}$ 'землянка' (cul' earth, $m \bar{x} t$ 'čum, house'), but Donner documented the same Ewenki loanword known among the Northern Ket in Taz Selkup as kărắljmo (Alatalo 2005: entry 2227). ${ }^{7}$

As the Forest Enetses have lived far more south in earlier days where earth huts were used more frequently, this ethnonym

6 A similar interpretation concerning a nowadays obsolete (Tundra?) Enets form baggo designating both Selkup and Ket was already given by Dolgix (1970: 194). baggo is indeed only an older variety of the word for hole in which the geminate was preserved and it is unclear why the lexeme hole alone should designate a people. Dolgix's assumption on the origin of the ethnonym were correct, but not the designating lexeme.

7 The Selkup form of Evenki golomo shows clear signs of phonological nativization such as a voiceless plosive in the onset. Also the trill in the onset of the second syllable points to nativization, but the necessary details need to be worked out. In Mikola's short notes on Selkup historical phonology, a $1 \rightarrow \mathrm{r}$ sound change is not mentioned (Mikola 2004: 85). This sound change is however attested in Forest Enets (see also Ratta) but it is too early to make any assumptions on a borrowing chain Evenki $\rightarrow$ (Forest) Enets $\rightarrow$ Northern Selkup as the lexeme golomo has never been reported for Forest Enets. Historically it is quite likely that Forest Enetses might have lived in earth huts, too, while living in more southern territories. Unfortunately, evidence is missing again. 
has survived the migration to the north. Whereas earth huts of the Evenki golomo type are known and were earlier used among the neighboring Dolgans, ${ }^{8}$ they are unknown among the Taimyrian Samoyedic people who used the conic tent and after increasing contacts with Russians, also the sled based balok.

\section{Contacts between Enetses and Kets}

Since Hajdú's article on early Samoyedic-Ket contacts (Hajdú 1953), possible contacts between the Yeniseic languages and the Samoyedic branch of Uralic have been discussed occasionally (for an overview see Siegl 2008). ${ }^{9}$ As the instance of pronoun borrowing from Ket into Forest Enets has no implications for possible earlier contacts, the discussion is restricted to the latter and attempts to localize a possible contact area. Due to the uniqueness of the Ket-Forest Enets language contacts, borrowing of personal pronouns paired with the absence of other borrowed lexical material, historical phonology and sound change as an auxiliary means for chronology cannot be used.

\subsection{Historical accounts}

The standard sources on the ethnic history of Samoyedic people, usually based on the analysis of old taxation lists (e.g. Dolgix 1970, Vasil'ev 1979) with further comments based on other archive materials, locate the first contacts between Forest Enetses and Kets in the 17th century on the left bank of the Yenisei around the area of Turuxansk; the fortification Mangazeja served as the north-western border of this territory (Dolgix 1970: 194ff, Vasil'ev 1979: 40-41, map in Dolgix 1970: 269). The contact zone on the left bank and its dating was accepted by the leading specialist in Ket ethnology (Alekseenko 2005a: 644).

8 This lexeme was also borrowed into Dolgan.

9 Concerning this topic, a paper by Filimonov (2008) has to be mentioned which appeared after the publication of Siegl (2008). 
Alekseenko further mentions that in the Northern contact area between Enetses and Kets, Kets started to use the same type of sleds as Nenetses and Enetses. ${ }^{10}$ Also the emergence of reindeer herding among Kets in the same area points to Northern Samoyedic, most probably Forest Enets influence (2005b: 656, 2005c: $658-660){ }^{11}$

Later, due to migration pressure from arriving Selkups and Evenkis, territorial division was reorganized. The left bank of the Yenisei became dominated by Selkups, the right bank by Evenkis. Whereas the Ket started to assimilate, the Forest Enetses migrated towards the Taimyr Peninsula. This migration brought only temporarily relief as the Forest Enetses soon experienced new territorial conflicts with the Tundra Nenetses who arrived from the west. Resulting occasional warfare which ended around 1850 changed the status-quo on the Taimyr Peninsula as the Enetses were driven away from the left bank of the Yenisei which fell under the hegemony of Tundra Nenetses. Since the 1850s, Forest Enetses predominantly inhabited the right bank of the Yenisei until the first decades of the 20th century (Siegl forthcoming). ${ }^{12}$

\subsection{A possible Forest Enets place name in Northern Evenkija and its implications}

Although the initial contacts between Forest Enetses and Kets must have taken place on the Yenisei, traces in the topon-

10 The same type of sleds was also taken over by the Northern Selkups.

11 Forest Enetses as inhabitants of the transitional area between taiga and tundra did not engage in large-scale reindeer herding typical for Tundra Nenetses until the enforcement of industrialized reindeer herding in the Soviet period.

12 Although the literature maintains that the division between a Nenets dominated left bank and an Enets dominated right bank was stable much longer, data gathered during my fieldwork suggests that several Forest Enets families started to live again on the left bank around the Dry Lake (ru: Cyхое озеpo) roughly $40 \mathrm{~km}$ opposite of Potapovo since the 1930s. The same seems to apply to the Tundra Enets diaspora in the Tuxard Tundra on the left bank of the Yensei. 
ymy are yet to be located. On the other side, a possible and so far unnoticed Forest Enets place name on the right side of the Yenisei exists - the name of the village Мадуйка. Madujka is located east of the Yenisei close to the river Курейка in Northern Evenkija $(66,39 \mathrm{~N} \mathrm{88,25} \mathrm{E})$, in an area where the northernmost speakers of Ket are found. ${ }^{13}$

\subsubsection{Madujka and mundujskoe ozero}

In the short historical overview of Ket ethnic history, the lake мундуйское озеро is explicitly mentioned by Alekseenko (2005a: 645) as an instance of borrowed Evenki toponymics on Northern Ket territory. The name of the lake is said to derive from Evenki мунду/nунду 'fish for profit' (рыбка для наживи) but the etymology as such is questionable when consulting Evenki dictionaries. ${ }^{14}$

Still, the name of the lake and the name of the village do not fit together and apparently, they derive from two different languages. As the final element $-j k a$ in Madujka is a standard component of place names, it is the first component that calls for attention. Concerning the etymology of Мадуйка, it could be connected to the Forest Enets lexeme madu which designates both Tundra Enetses and Nganasans in contemporary Forest Enets. Also, the location of Мадуйка south of contemporary Forest Enets territories is in concordance with earlier accounts on the migration history of Enetses. ${ }^{15}$

Still, this proposed etymology of Madujka as "Enets place" is not safe from criticism, and this must be stated clearly. First, the contemporary use of madu in Forest Enets means "speaker

13 Ket is on the verge of extinction in Madujka. Fieldtrips in 2002/2003 found six elderly speakers left. (Glazunov \& Nefëdov 2004)

14 In Evenki dictionaries available to me (Boldyrev 1985, Myreeva 2004), мунду and пунну designate a Siberian fish from the carp family, in Russian 'гольян' (lat: Phoxinus Phoxinus). Myreeva states, that the Evenki word is borrowed from Yakut. (Myreeva 2004: 375; 482)

15 Note also the Selkup family name Мандаков from an adjacent area on the other side of the Yenisei. 
of a Samoyedic language in the North." As far as the Enets ethnonyms have been investigated in research (see Siegl 2005 for a survey on the literature), madu was never documented among the Tundra Enetses but only among the Forest Enets to designate Tundra Enetses and Nganasans. Further, earlier research has convincingly proven that an autochthonous self-designation among the Enetses was missing; Tundra Enetses referred to themselves as somatu and Forest Enetses had apparently no collective self-designation and either the clan name was used or one simply identified oneself as d'urak, which is of course the Enets version of the Tundra Nenets ethnonym. However, evidence from the neighboring Samoyedic languages shows a slightly different picture. First, Xelimskij (2000: 82-85) has shown, that the Tundra Enets self-designation somatu is most probably of Nganasan origin and therefore not of very old age. Second, local Taimyrian Nenetses generally refer to Enetses as manto, the etymological cognate of madu. If Forest Enetses are referred to, the ethonym wei which is the cognate of the Enets bai clan is used. Most usually, Taimyrian Nenetses refer to Forest Enetses as wei manto. ${ }^{16}$ Although not finally provable, there is some evidence that madu as a more holistic designation of Enetses seems possible in an earlier period..$^{17}$ The Selkup family name Манда$к о в$ is also favorable for such an interpretation. This brings us to the next question - who would have introduced and used a possible place name Madujka? As contemporary Northern Selkup and Ket do not show a distinction between Nenets and Enets in the designation of their neighbors (and as far as it possible to reconstruct, never did) and as the same seems to hold for Evenkis, there seems to be no obvious answer to this question. In my

16 This so far unmentioned practics were uncovered during fieldwork in summer 2011.

17 The two other Taimyrian indigenous languages Evenki and Dolgan do not have a specialized designation for Enetses. Evenkis simply classify Enetses as Nenetses. From the perspective of Dolgan, two different strategies could be documented in summer 2011. Tundra Enetses living among the Nganasan in Ust-Avam and Voločanka were usually called haamai as the Nganasans. Tundra Enetses living further away among the Nenetses were called d'urak, as Tundra Nenetses. 
opinion, the unusual case of language contact as addressed in Siegl (2008) may offer a tentative answer. The borrowing of pronominal stems without any lexification in either direction must have resulted from the assimilation of a Ket community which has switched to Forest Enets during a very short period of time in a very small and restricted area. As Madujka is located in the periphery of the Ket territory and on the migration path of the Forest Enetses towards the Taimyr Peninsula, a small local Ket speech community under heavy assimilation pressure with Forest Enetses could have started to use the term madu to designate a contact area. As this naming pattern was strictly local, it could not spread and no specialized name for (Forest) Enetses among the Ket resulted.

The assimilation assumption would fit Alekseenko's observation that Northern Kets took over Samoyedic sleds and reindeer herding which shows that significant assimilation pressure can be assumed. ${ }^{18}$ Finally, the fact that Kets frequently shifted towards neighboring languages in language contact situations is well established in the literature (e.g. Donner 1933: 14) and offers further support.

\subsubsection{Thoughts on a possible chronology}

As already mentioned above, the absence of Forest Enets borrowings in Ket as well as other Ket borrowings in Forest Enets apart from the pronominal stems for 2nd and 3rd person means that historical phonology and sound change cannot be applied. As terminus ante quem serves Castrén's comparative grammar which shows, although not immediately comprehensible for the outsider, that Forest Enets uses different pronouns

18 In contrast, local Evenkis did not engange in reindeer herding nor did they adopt this speficic type of transportation. Such topics also dominante Samoyedic folklore on the Taimyr Peninsula which frequently reports warfare with tattooed Evenki who arrived on foot and owned no reindeer. Similar tensions between Kets and Evenkis were mentioned by Donner (1933: 14). 
for 2nd and 3rd person in comparison with Tundra Enets (Castrén 1854: 350-353). As terminus post quem, the split of Tundra Enets and Forest Enets is a logic condition, but this split has never been attempted to date and therefore offers no support. Further, as taxation lists on which Dolgix (1970) and Vasil'ev (1979) are based start only with the advent of the Russian state in the early 17 th century, it is not even clear, if possible (Forest) Enets - Ket contacts did really start as late as the 17th and 18th century. Although outside the scope of this paper, it may be possible that common Enets before its split into two languages had contacts with Ket or other Yeniseic languages. For Yeniseic in general, a phonotactic restriction concerning consonant clusters in word internal position is characteristic. Werner mentions for both, the extinct Kott language as well as the moribund Ket language, that word-internal clusters are usually avoided (Werner 1997a: 36; 1997b: 29). In this concern, Enets as a whole differs from all other Samoyedic languages as it abolished many medial consonant-clusters which are preserved elsewhere: "Der enzische Konsonantismus zeigt eine ziemlich eigenartige Entwicklung. Es haben sich in dieser Sprache Lautentwicklungen abgezeichnet, wie sie in der uralischen Sprachfamilie nirgendswo anders vorkommen. Vor allem verdient die Entwicklung der Glottisverschlusslaute und der Konsonantenverbindungen Aufmerksamkeit" (Mikola 2004: 65). Also the glottal stop is at least a strong areal feature uniting Northern Samoyedic and Yeniseic, even if the historical background in 2012 is as unclear as it was in 1986: "In view of what can be assumed about the absolute and relative chronologies of Yeniseic and Samoyedic, this circumstance [existence of a glottal stop - F.S.] may imply that the Yeniseic glottal stop has diachronically more ancient roots than its phonetic counterpart in Samoyedic. If this assumption is correct, the Yeniseic glottal stop may, indeed, have constituted a relevant external factor, supporting the origination of the glottal stop phoneme in Samoyedic. However, much more research in the ethnic and linguistic history of the Samoyedic and Yeniseic speech communities is required before anything certain can be said about such a possible connection." (Janhunen 1986: 168). 
However, the last two mentioned phenomena pre-date Forest Enets-Ket contacts which were the topic of this paper.

\section{Conclusion}

In this paper, I have addressed Enets traces along their migration path towards the Taimyr Peninsula. Whereas earlier research has shown such traces on the territory occupied by Northern Selkups, all of them on the left side of the Yenisei, I have tried to show that there is a possible Enets place name on the right side of the Yenisei along the river Kurejka, the name of the village Madujka. As this place is also the northernmost area of Ket, this area could have served as the possible contact area in which the pronoun borrowing scenario of Forest Enets could be located. From the perspective of Forest Enets, it is to be wished that further work on the last remaining Yeniseic language should produce more data on Northern Ket, especially lexicographic. ${ }^{19}$ First, if the proposed etymology for Madujka is correct, other traces of Enets might be observable in the toponomy. Second, as the lexicon of Northern Ket is apparently not fully covered, the general picture of missing lexification in the Forest EnetsKet pronoun borrowing scenario should not be seen as finally proven. In the initial paper (Siegl 2008) I have mentioned that there were no new loanword candidates based on a scanning of Werner (2002), but this statement is not final for as long as there is no new data from Northern Ket.

The current state of knowledge concerning the Forest Enets - Ket pronoun borrowing scenario is continuously challenging for apparently all theories of language contact. Forest Enets is neither a mixed language nor has it undergone creolization and as research history has demonstrated, Forest Enets could be firmly integrated into historical-comparative Samoyedic lin-

19 In their overview of their fieldwork in Madujka in 2003, Glazunov and Nefëdov have complained that research on Ket has been concentrating mainly on Middle- and Southern Ket varieties and neglected Northern Ket for a long while. 
guistics. Only the pronominal stems for 2 nd and 3 rd person have a history of their own.

\section{Address:}

Florian Sieg1

Department of Finnish, Finno-Ugrian

and Scandinavian Studies

University of Helsinki

P.O. Box 24

00014 University of Helsinki

E-mail: florian.siegl@helsinki.fi

\section{References}

Alatalo, Jarmo (2004) Sölkupisches Wörterbuch aus Aufzeichnungen von Kai Donner, U. T. Sirelius und Jarmo Alatalo. (Lexica Societatis FennoUgricae, 30.) Helsinki: Finno-Ugrian Society.

Alekseenko, E. A. (2005a) "Osnovnye ètapy ètničeskoj istorii". In I. N. Gemujev et al. Narodov zapadnoj Sibiri: Xanty. Mansi. Sel'kupy. Nency. Ency. Nganasany. Kety, 641-647. Moskva: Nauka

Alekseenko, E. A. (2005b) "Xozjajstvo". In I. N. Gemujev et al. Narodov zapadnoj Sibiri: Xanty. Mansi. Sel'kupy. Nency. Ency. Nganasany. Kety, 648-656. Moskva: Nauka.

Alekseenko, E. A. (2005c) "Material'naja kul'tura". In I. N. Gemujev et al. Narodov zapadnoj Sibiri: Xanty. Mansi. Sel'kupy. Nency. Ency. Nganasany. Kety, 657-686. Moskva: Nauka.

Boldyrev, B. O. (1985). Russko-èvenkijskij slovar'. Novosibirisk: Nauka.

Castrén, Matthias Alexander (1854) Grammatik der samojedischen Sprachen. Herausgegeben von Anton Schiefner. St. Peterburg: Buchdruckerei der Kaiserlichen Akademie der Wissenschaften.

Dolgix, B. O. (1970) Očerki no ètničeskoj istorii nencev i èncev. Moskva: Nauka.

Donner, Kai (1933) Ethnological notes about the Yenisey-Ostyak (in the Turukhansk region). (Mémoires de la Société Finno-Ougrienne, 64.) Helsinki: Finno-Ugrian Society.

Erdélyi, István (1970) Selkupisches Wörterverzeichnis: Tas Dialekt. (Indiana University Publications. Uralic and Altaic Series, 103.) Bloomington and Hague: Mouton. 
Filimonov, M. V. (2008) "Jenisejskij ingredent v prasamodijskom: fonologičeskoe i morfologičeskoe diagnostirovanie”. In M.D. Ljublinskaja et al. Materialy 2-j meždunarodnoj konferencii po samodistike, 234244. Sankt-Peterburg: Nestor-Istorija.

Gemujev, I. N. (et al.) (2005) Narodov zapadnoj Sibiri: Xanty. Mansi. Sel'kupy. Nency. Ency. Nganasany. Kety. Moskva: Nauka

Glazunov, P. Ju. and Nefëdov, A. V. (2004) "Severnye kety: poslednie stranicy (po itogam lingvističeskoj èkspedicii 'Madujka' 2003”. In Sravnitel'noistoričeskie i tipologičeskie issledovanija jazyka i kul'tury: problemy $i$ perspektivy, 161-173. (Sbornik naučnyx trudov laboratorii jazykov narodov Sibiri, 2.) Tomsk: Tomskij gosudarstvennyj pedagogičeskij universitet.

Hajdú, Peter (1953) "Die ältesten Berührungen zwischen den Samojeden und den jenisseischen Völkern". Acta Orientalia 3, 73-101.

Janhunen, Juha (1986) Glottal stop in Nenets. (Mémoires de la Société FinnoOugrienne, 196.) Helsinki: Finno-Ugrian Society.

Klobystin, Leonid. P. (2005) Taymyr - the archeology of northernmost Eurasia. (Contributios to Circumpolar Anthropology, 5.) Washington: Smithsonian Institution.

Kuznecova, A. I. et al. (1993) Očerki po sel'kupskomu jazyku 2. Tazovskij dialekt. Moskva: Izdatel'stvo moskovskogo gosudarstvennogo universiteta.

Mikola, Tibor (2004) Studien zur Geschichte der samojedischen Sprachenaus dem Nachlass herausgegeben von Beáta Wagner-Nagy. (Studia Uralo-Altaica, 45.) Szeged: SzTE Finnugor Tanszék.

Myreeva, A. N. (2004) Èvenkijsko-russkij slovar'. Novosibirsk: Nauka.

Prokof'ev, G. N. (1935) Sel'kupskaja grammatika. (Naučno-issledovatel'skaja associacija Instituta narodov Severa CIK SSSR. Trudy po lingvistike, Tom IV B. 1.) Leningrad: Izdatel'stvo Instituta narodov severa CIK. SSSR.

Siegl, Florian (2005) "Where have all the Enetses gone?". In Art Leete and Ülo Valk, eds. The northern peoples and states: changing relationships, 235-253. (Studies in Folk Culture, 5.) Tartu: Department of Ethnology and Folkloristic.

Siegl, Florian (2008). "A note on personal pronouns in Enets and Northern Samoyedic". Linguistica Uralica 44, 119-130.

Siegl, Florian (forthcoming) Materials on Forest Enets, an indigenous language of northern Siberia. [MSFOu]. Reworked version of Siegl, Florian (2011) Materials on Forest Enets, an indigenous language of northern Siberia (Dissertationes Philologiae Uralicae Universitats Tartuensis, 9.) Tartu: Tartu University Press.

Tučkova, N. A. (2005) “Material'naja kul'tura”. ”. In I. N. Gemujev et al. Narodov zapadnoj Sibiri: Xanty. Mansi. Sel'kupy. Nency. Ency. Nganasany. Kety, 329-350. Moskva: Nauka.

Tereščenko. N. M. (1965). Nenecko-russkij slovar'. Moskva: Sovetskaja Ènciklopedija. 
Vasil'ev, V. I. (1979) Problemy formirovanija severosamodijskix narodnostej. Moskva: Nauka.

Werner, Heinrich (1997a) Die ketische Sprache. (Tunguso-Sibirica, 3.) Wiesbaden: Harrasowitz.

Werner, Heinrich (1997b) Abriss der kottischen Grammatik (Tunguso-Sibirica, 4.) Wiesbaden: Harrasowitz.

Werner, Heinrich (2002) Vergleichendes Wörterbuch der Jenissej-Sprachen I-III. Wiesbaden: Harrasowitz.

Xelimskij, E. A. (2000) "Ėtimologičeskie zametki po èneckoj onomastike". In E. A. Xelimskij. Komparativistika, Uralistika - lekcii i stat'i, 82-93. (Studia Philologica). Moskva: Jazyki russkoj kul'tury.

Kokkuvõte: Florian Siegl: Veelkord metsaeenetsi ja keti kontaktidest. Artiklis vaadeldakse eenetsite jälgi nende migratsiooni teel Taimõri poolsaarele. Erilist tähelepanu pööratakse metsaeenetsite ja keti kontaktidele ning pakutakse metsaeenetsi etümoloogia keti ja sölkupi etnonüümile. Lisaks diskuteeritakse kriitiliselt ühte võimaliku eenetsi kohanime Evengi munitsipaalrajoonis põhjas. Tõenäoliselt leidis sel alal aset ebaharilik keelekontakt metsaeenetsite ja põhjaketide vahel, mille käigus laenas metsaeenetsi keel keti keelest teise ja kolmanda isiku asesõnade tüved (Siegl 2008).

Märksõnad: toponüümid, keelekontaktid, tundraeenetsid, metsaeenetsid, sölkupid, ketid, jenissei keeled 
